\title{
Guidelines on the ethics of clinical research in anesthesia
}

\author{
Richard Hall, MD · David McKnight, MD • \\ Robin Cox, MBBS · Tom Coonan, MD
}

Received: 23 August 2011/ Accepted: 14 September 2011/Published online: 29 October 2011

(C) Canadian Anesthesiologists' Society 2011

\section{For the benefit of our readers and researchers}

- There are no other comparable guidelines which apply specifically to the ethical conduct of research carried out during the practice of anesthesia.

- This document was originally developed as a guide for researchers and Research Ethics Boards in Canada as to what practices were considered to be ethically acceptable and under what circumstances for the conduct of anesthesia related research e.g., the question of the appropriateness of obtaining informed consent for research purposes while the patient is in the preoperative holding area immediately prior to surgery. The current document is a revision and incorporates the tenets of the revised Tricouncil Policy Statement Version 2.

- The only other relevant guideline is that developed by the critical care community (Luce JM et al. The ethical conduct of clinical research involving critically ill patients in the United States and Canada: Principles and recommendations. Am J respire Crit Care Med 2004;

This study was conducted for the Ethics Committee of the Canadian Anesthesiologists Society.

R. Hall, MD $(\bowtie) \cdot$ T. Coonan, MD

Dalhousie University, Halifax, NS, Canada

e-mail: rihall@dal.ca

D. McKnight, MD

University of Toronto, Toronto, ON, Canada

R. Cox, MBBS

University of Calgary, Calgary, AB, Canada
170: 1375-84). While some of the issues e.g., the question of competence and ability to provide informed consent under stressful circumstances are similar, the present guidelines are focused on the perioperative period and specific to the conduct of research within the context of the delivery of anesthesia care.

- Anesthesia research encompasses the field of perioperative medicine including the preoperative period in contrast to the critical care guidelines which focus on a different population of patients.

These revised guidelines were prepared by the Canadian Anesthesiologists' Society's Ethics Committee to assist investigators in consideration of the ethical issues involved in anesthesia research with human subjects. These guidelines cannot be an exhaustive treatment of the subject, nor advise on every study design. Investigators are urged to use these guidelines, to discuss the relevant issues with local ethics consultants and use the resources of local Research Ethics Boards in keeping with the Tri-Council Policy Statement, Ethical Conduct for Research Involving Humans. $^{\mathrm{A}}$

\section{Preamble}

As part of its mandate to promote high-quality research, the Canadian Anesthesiologists' Society recognizes the need to ensure appropriate moral and ethical behaviour on the part of investigators who conduct clinical research with human subjects in Canada.

\footnotetext{
A Joint publication of the Canadian Institutes of Health Research, the Natural Sciences and Engineering Research Council of Canada, and the Social Sciences and Humanities Research Council of Canada, August 2010 www.pre.ethics.gc.ca.
} 


\section{Moral framework}

For human research, in anesthesia as in any other specialty, investigators are expected to comply with the Tri-Council Policy Statement, Ethical Conduct for Research Involving Humans Version 2 which uses a principle-based framework. Its "cardinal principle", is respect for human dignity. Ethical principles such as respect for free and informed consent, respect for privacy and confidentiality, beneficence (maximizing benefits), non-maleficence (minimizing harm), and respect for justice and inclusiveness must be carefully weighed in circumstances where they may be in conflict.

Requirement for research ethics board approval

Researchers may carry out research protocols only after approval is obtained from an appropriate institutional Research Ethics Board (REB). The REB should also be responsible for monitoring the progress of each study.

Specialty specific areas for consideration

It is apparent that a number of specialty-related ethical dilemmas arise with certain research protocols. In the unique environment of anesthesia, these include factors such as:

1. Determining how, when, and by whom patients should be approached for consent.

2. Adequate time for patients to reflect on the protocol, and their ability to withdraw at any time. In the latter context, it is recognized that clinical trials involving general anesthetics or other potent central nervous system depressant medications necessarily limit the patient's ability to withdraw from the study at some times.

Because of such ethical dilemmas, the Canadian Anesthesiologists' Society supports the thoughtful interpretation and application of existing guidelines and ethical principles to each human research protocol.

\section{Research with human subjects}

\section{Informed consent}

Ethical conduct of research requires that informed consent be obtained from participating subjects, or from an appropriate legally responsible delegate. ${ }^{\mathrm{B}}$ Information

\footnotetext{
B While obtaining consent from a legally responsible or legally authorized representative is accepted in the context of therapy, it is still not without controversy in the research context. The issue of recruiting potentially incapable persons in anesthesia research must be carefully considered by the local Research Ethics Board.
}

regarding the purpose of the study must be explained to prospective subjects or participants in lay terms. The consent form must also state that the individual may refuse to participate, or is free to withdraw from participation, at any time without prejudice to his or her medical care (see Appendix: Sample Consent Form).

Timing of obtaining informed consent for research

The amount of time required for patients to make an informed decision about participating in research is an important issue. A problem may arise in anesthesia because anesthesia investigators may not have their first contact with patients until they are in hospital, often on the same day as their scheduled surgical procedure. If prior contact with potential study participants is required by the Research Ethics Board, such contact by a "stranger" either at work or at home, could be perceived by the patient as an invasion of privacy. Conversely, if the investigator will also be the patient's clinical anesthesiologist there is a duty-of-care relationship, and such an approach might be considered coercive. The balance between competing ethical considerations must be carefully evaluated for each research protocol.

The Canadian Anesthesiologists' Society believes that pre-operative consent for clinical research in anesthesia may be obtained after admission to hospital, either before or on the day of the scheduled surgery provided that:

1. Patients are not under the influence of premedication.

2. Risk to the patient is not significantly different from routine clinical care.

3. After verbal explanation from the investigator or research assistant, patients are given time to read the information sheet and consider the risks and benefits.

4. Patients are given an opportunity to raise any further questions or seek clarification on any points concerning the nature of the study, alternatives, risks, benefits, etc.

5. Patients who feel they are under duress, or require more time to make a decision should be excluded from further participation in the study.

6. Investigators document in the health care chart the nature of their consent process for participants who agree to participate in a research protocol.

Personnel approaching participants for consent

For protocols that require participants to receive advance information because of additional risk to or time commitment from the patient or for administrative reasons connected with the protocol, the principal investigator and the REB should 
agree upon an ethical and practical mechanism to provide this information. ${ }^{\mathrm{C}}$

Privacy and patient confidentiality

Privacy involves the right of the study participant to decide the extent to which there is access to personal data that is not already in the public domain. Confidentiality involves the preservation of the subject's anonymity when handling data during research and during its subsequent use in teaching, scholarly presentations, and in publication.

As with any clinical research, privacy and confidentiality must be respected at all times. Investigators should be aware of relevant law restricting the use of personal health information for research purposes in their respective jurisdictions. In this regard, the nature and type of information that is accessed for study purposes should be documented, and if that information is to be used for other reasons, participants should be made aware of this as part of the consent process.

\section{The potential for risks and benefits}

The nature of many clinical trials in anesthesia (e.g., comparison of the recovery characteristics and cost/benefit ratios of different types of general anesthetics) is such that the primary risk is that of the anesthetic itself, not participation in the study protocol. On the other hand, use of invasive monitoring techniques to evaluate cardiovascular effects of a new anesthetic agent may involve the risk of rare but potentially serious complications. It is always the responsibility of the investigator and the REB to ensure that potential benefits outweigh the possible risks.

When consenting to participation in research, participants accept the possibility of risks and benefits. The probability of risk and the magnitude and character of potential harm must be disclosed. The likelihood of a given risk, its duration and likely reversibility must be assessed. Investigators must also be prepared to demonstrate that

\footnotetext{
$\overline{\mathrm{C}}$ As examples, in centres where the research nurse is viewed as part of the departmental team and may contact potential research patients in advance, the research nurse may notify patients of his/her role as a member of the team and ask if they are interested in participating in a research study. If the patient is interested, the research study nurse explains the study and obtains consent. Consent is then obtained in writing at the earliest opportunity. This is accepted practice by some Research Ethics Boards. In situations where this approach is not acceptable to the respective REB, and for studies involving more than minimal risk, patients may be seen and consented in the Preoperative Assessment clinic. The anesthesiologist should enquire as to whether or not the patient is interested in participating in a research study, and if the answer is affirmative, a member of the research staff may then approach the patient to present the study details and seek informed consent.
}

there is no reasonable alternative methodology that would avoid or reduce possible risks.

Benefits may include potential advantages to the subject, future patients, third parties, society or a segment thereof, and any general increase in human knowledge.

\section{Placebos}

Use of a placebo medication as the control arm in an anesthesia protocol is unethical when there is an established effective treatment for the condition under investigation. ${ }^{\mathrm{D}}$ Legitimate use of placebos is based on the concept of clinical equipoise, which exists only when there is genuine uncertainty among experts about the relative therapeutic merits of the two arms of a clinical trial. It is expected that a clinical trial will be designed so that, if successful, it will provide evidence in favour of one of the treatments. $\mathrm{E}$

For ethical use of a placebo control there must be genuine disagreement among expert practitioners as to preferred treatment. "A nonvalidated treatment may be compared with a placebo control if (1) no standard therapy exists, (2) standard therapy exists but has been shown to be no better than placebo, (3) standard therapy is placebo, (4) standard therapy is toxic and of marginal benefit, or, (5) validated treatment exists but is not available because of cost or limited supplies. Placebo controls are appropriately used when the new, nonvalidated treatment is an 'add-on' to standard therapy (so that the comparison is standard therapy plus new drug versus standard therapy plus placebo)." $\mathrm{F}$

\section{Conflicts of interest}

All potential conflicts of interest must be declared to participants in a clinical trial and included in the consent form and any subsequent publications. Financial or material rewards to investigators must also be declared to the Research Ethics Board. Clinical care must always take precedence over research investigation. When the same anesthesiologist will be both investigating research participants and providing their anesthetic care, the research protocol as approved by the Research Ethics Board must have clear indications as to when the study protocol will be abandoned for the wellbeing or safety of the individual patient.

\footnotetext{
$\overline{\mathrm{D}}$ Tri-Council Policy Statement, www.pre.ethics.gc.ca.

E Freedman B. Equipoise and the ethics of clinical research. N Engl J Med 1987; 317: 141-5.

F Huston P, Peterson R. Withholding proven treatment in clinical research. N Engl J Med 2001; 345: 912-4.
} 
Remuneration to study participants

Research participants must not be offered rewards so great as to coerce them to take risks in research that they would not otherwise consider reasonable. Equally, research participants must not be expected to subsidize research by suffering monetary or other losses. Bearing these concepts in mind, the amount and type of remuneration must be disclosed to the Research Ethics Board.

Vulnerable populations

These populations include patients who lack decisionmaking capacity, patients of questionable capacity, and those who may be "capable" but vulnerable because of a disease process, culture, or inability to speak a language. Patients undergoing surgery may feel stressed and are potentially vulnerable to coercion-particularly if the treating and investigating physician are the same person. It is unethical to take advantage of vulnerable populations and anesthesiologists should consider this aspect in recruiting participants to a clinical study. In general, capable people should be enrolled where possible over those who are incapable or of questionable capacity.

Gender specific and Pediatric studies

Research protocols must use appropriate models and populations, taking into consideration issues of gender and age. In particular, it is important that there be on-going research in anesthesia in women of child-bearing capacity and for the pediatric population as it would be unethical to deny these groups the benefits of advances in the specialty. Investigators and Research Ethics Boards have a particular duty to protect child participants and those from other vulnerable populations from undue risk of harm, especially when consent or permission is obtained through another person. Assent for research should be obtained from children of appropriate age as determined in consultation with the Research Ethics Board.

\section{Competence}

Competence to consent to research does not require that patients be competent in all respects for all purposes. Decision making capacity is not a global assessment but a functional assessment and is decision specific. For example, a patient who is incapable of managing financial affairs may be competent to consent to research.

In conducting research that might involve cognitively impaired persons, the protocol must include an assessment of competence. Furthermore, a person who is incompetent, or of doubtful competence, must not be included in research that poses more than minor risks without substantial potential benefits for that person. In addition, if incompetent persons are to be enrolled, the researcher must explain to the REB how third party authorization will be obtained, and that the subject's interests are protected.

\section{Appendix: 2011 GUIDELINES TO THE PRACTICE OF RESEARCH IN ANESTHESIA}

\section{SAMPLE CONSENT FORM}

\section{Research Project}

Investigators

Funding Agency

This consent form, a copy of which has been given to you, is only part of the process of informed consent. It should give you the basic idea of what the research project is about and what your participation will involve. If you would like more detail about something mentioned here, or information not included here, you should feel free to ask. Please take the time to read this carefully and to understand any accompanying information.

(The investigators should supply the following information in ordinary language, avoiding jargon and supplying explanations for crucial terms. This is a sample consent form, so if any item is obviously irrelevant it need not be included. N.B. Most local Research Ethics Boards have similar consent form templates which should be used).

1. Purpose of the research.

2. Description of all experimental agents and procedures, including identification of those that would not be a part of routine therapeutic care.

3. Explanation of such aspects of research design as randomization and double-blinds. In the case of double-blinds, details of when a code may be broken, debriefing and final consent after debriefing should be included.

4. Description of the likelihood of any discomforts and inconveniences associated with participation and of known or suspected short- and long-term risks.

5. Detailed descriptions of exactly what participation will entail (regular routines, time commitment, natures of tests and procedures, etc.).

6. Probability and nature of direct and indirect benefits to the subjects themselves and to others.

7. Identification of alternatives to enrollment in the research, with discussion of the risks, benefits, etc. of these alternatives. (Where appropriate, this disclosure 
may be verbal or supplementary to the consent form and referred to at this point).

8. Explanation of who will have access to information collected and the identity of the subject, including a description of how confidentiality will be protected.

9. Explanation of how the subjects will receive new or updated information during the course of the research.

10. Description of any financial costs the subject may incur as a condition of or because of participation in the research.

Your signature on this form indicates that you have understood to your satisfaction the information regarding your participation in the research project and agree to participate as a subject. In no way does this waive your legal rights nor release the investigators, sponsors, or involved institutions from their legal and professional responsibilities. You are free to withdraw from the study at any time without jeopardizing your health care. Your continued participation should be as informed as your initial consent, so you should feel free to ask for clarification or new information throughout your participation. If you have further questions, please contact:

Name of responsible investigator or qualified designate

Address with contact phone number

(Signature of subject, or responsible proxy)

Name of Witness

Signature of Witness

Date

\section{Other resources}

1. World Medical Association. Declaration of Helsinki. Recommendations Guiding Medical Doctors Involving Human Subjects. Available from URL: www.wma.net/en/20activities/ 10ethics/10helsinki/index.html (accessed August 2011).

2. Luce JM, Cook DJ, Tramer TR, et al. The ethical conduct of clinical research involving critically ill patients in the United States and Canada: principles and recommendations. Am J Resp Crit Care Med 2004; 170: 1375-84.

3. Weijer C, Dickens B, Meslin EM. Bioethics for clinicians: 10 . Research ethics. CMAJ 1997; 156: 1153-7.

4. ICH. WHO: Guidelines for Good Clinical Practice for Trials on Pharmaceutical Products ICH E6 (R1): Good Clinical Practice: Consolidated Guidance. Available from URL: www.ich.org (accessed August 2011).
5. Guidance for Clinical Investigators, Sponsors, and IRBs Adverse Event Reporting to IRBs - Improving Human Subject Protection U.S. Department of Health and Human Services; Food and Drug Administration; Office of the Commissioner (OC); Center for Drug Evaluation and Research (CDER); Center for Biologics Evaluation and Research (CBER); Center for Devices and Radiological Health (CDRH); Good Clinical Practice Program (GCPP) January 2009. Available from URL: http://www.fda. gov/downloads/RegulatoryInformation/Guidances/UCM126572. pdf (accessed August 2011).

6. Health Canada. Drugs \& Health Products. Compliance \& Enforcement. Good Clinical Practices. Regulations. Available from URL: www.hc-sc.gc.ca (accessed August 2011).

7. Office of the Privacy Commissioner of Canada. Personal Information Protection and Electronic Documents Act (PIPEDA). Available from URL: www.priv.gc.ca (accessed August 2011). Readers should also consult relevant provincial privacy legislation.

8. Weijer C. The ethical analysis of risk. J Law Med Ethics 2000; 28: 344-61.

\section{Directives sur l'éthique de la recherche clinique en anesthésie}

\section{Pour le bénéfice de nos lecteurs et chercheurs}

- Il n'existe pas de guide comparable qui s'applique spécifiquement à la conduite éthique des recherches réalisées pendant la pratique de l'anesthésie.

- À l'origine, ce document a été mis au point pour servir de guide aux chercheurs et aux Comités d'éthique de la recherche au Canada concernant les pratiques considérées comme déontologiquement acceptables et les circonstances nécessaires à la conduite de recherches liées à l'anesthésie - en abordant par exemple la question de savoir s'il convient d'obtenir le consentement éclairé à des fins de recherche pendant que le patient se trouve dans la salle d'attente immédiatement avant la chirurgie. Le présent document est une révision et intègre les principes de l'Énoncé de politique révisé des trois conseils, $2^{\mathrm{e}}$ version.

- Le seul autre guide pertinent est celui mis au point par la communauté des soins intensifs (Luce JM et al. The ethical conduct of clinical research involving critically ill patients in the United States and Canada: Principles and recommendations. Am J respire Crit Care Med 2004; 170: 1375-84). Bien que certains des sujets abordés soient semblables, comme par exemple la question de la compétence et de la capacité à fournir un consentement éclairé dans une situation stressante, ces directives-ci portent surtout sur la période périopératoire et spécifiquement sur la conduite de la recherche dans le contexte de dispensation de soins en anesthésie. 
- La recherche en anesthésie recouvre le domaine de la médecine périopératoire, y compris la période préopératoire, à la différence des directives pour les soins critiques, qui intéressent une population de patients différente.

Ces directives révisées ont été préparées par le Comité de déontologie de la Société canadienne des anesthésiologistes afin d'aider les chercheurs à cerner les enjeux éthiques de la recherche en anesthésie sur des sujets humains. Ces directives ne sauraient être exhaustives ni aborder tous les modèles possibles d'études. Nous encourageons les chercheurs à utiliser ces directives, à discuter des enjeux pertinents avec les experts-conseils en éthique de leur milieu et à faire appel aux ressources des comités locaux d'éthique de la recherche, conformément à l'Énoncé de politique des trois conseils intitulé Éthique de la recherche avec des êtres humains. ${ }^{\mathrm{A}}$

\section{Préambule}

La Société canadienne des anesthésiologistes, dont la mission est de promouvoir la recherche de haute qualité, reconnaît la nécessité de garantir que les chercheurs faisant de la recherche clinique au Canada avec des sujets humains se comportent d'une manière respectant les règles morales et éthiques indiquées.

\section{Cadre moral}

On attend des chercheurs qui utilisent des sujets humains dans leurs recherches en anesthésie, comme dans toute autre spécialité, qu'ils se conforment à l'Énoncé de politique des trois conseils, Éthique de la recherche avec des êtres humains, $2^{e}$ édition, qui s'appuie sur un certain nombre de principes. Le 'principe cardinal' est le respect de la dignité humaine. Les principes éthiques comme le respect du consentement libre et éclairé, le respect de la vie privée et de la confidentialité, la bienfaisance (optimisation des avantages), la non-malfaisance (minimisation des torts), et le respect de la justice et de l'intégration doivent être soigneusement soupesés dans les circonstances où ils risquent d'être en conflit.

Exigence de l'approbation du comité d'éthique de la recherche

Les chercheurs ne peuvent exécuter des protocoles de recherche qu'après avoir obtenu l'approbation du comité

\footnotetext{
A Publication conjointe des Instituts de recherche en santé du Canada, du Conseil de recherches en sciences naturelles et en génie du Canada, et du Conseil de recherches en sciences humaines du Canada, août 2010, www.pre.ethics.gc.ca.
}

d'éthique de la recherche (CÉR) institutionnel indiqué. Ce CÉR aura aussi la responsabilité de suivre l'avancement des travaux de chaque étude.

Domaines spécifiques à la spécialité dont il faut tenir compte

Il est clair que certains protocoles de recherche posent un certain nombre de dilemmes éthiques liés à la spécialité en question. Dans le cas particulier de l'anesthésie, ces dilemmes portent sur des facteurs tels que:

1. Déterminer comment, quand et par qui les patients devraient être approchés pour obtenir leur consentement.

2. Donner aux patients suffisamment de temps pour réfléchir au protocole et la possibilité de s'en retirer en tout temps. À ce dernier égard, on admet que les essais cliniques comportant des anesthésiques généraux ou d'autres puissants dépresseurs du système nerveux central limitent nécessairement la capacité du patient à se retirer de l'étude à certains moments.

En raison de ces dilemmes éthiques, la Société canadienne des anesthésiologistes est favorable à l'interprétation et à l'application pondérées des directives existantes et des principes éthiques à chacun des protocoles de recherche comportant des sujets humains.

\section{Recherche avec des êtres humains}

Consentement éclairé

La conduite éthique de la recherche exige l'obtention du consentement du sujet participant à une recherche ou de la personne légalement habilitée à la remplacer. ${ }^{B}$ Il faut expliquer l'objectif de la recherche aux sujets ou participants éventuels en termes simples. Le formulaire de consentement doit aussi préciser que la personne peut refuser de participer à la recherche ou est libre de cesser d'y participer en tout temps sans que les soins médicaux qu'elle reçoit en souffrent d'aucune manière. (Voir Annexe: Modèle de formulaire de consentement).

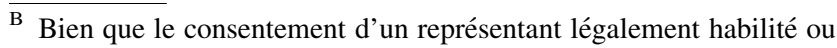
autorisé soit accepté dans le contexte thérapeutique, il ne va pas sans controverse dans le contexte de la recherche. Le recrutement pour la recherche en anesthésie de personnes potentiellement inaptes doit être soigneusement étudié par le comité d'éthique de la recherche local.
} 
Moment de l'obtention du consentement éclairé pour la recherche

Le temps qu'il faut à un patient pour prendre une décision éclairée au sujet de sa participation à une recherche est une question importante. Un problème peut survenir en anesthésie, parce que le chercheur de cette discipline ne rencontrera peut-être le patient pour la première fois que lorsqu'il est à l'hôpital, et souvent le jour même où il doit subir son intervention chirurgicale. Dans le cas où le comité d'éthique de la recherche a exigé une prise de contact antérieure avec les sujets éventuels de la recherche, un patient pourrait interpréter un tel contact avec un 'étranger' au travail ou chez lui comme une atteinte à sa vie privée. Inversement, si le chercheur est aussi l'anesthésiologiste clinicien du patient, il aura envers lui un devoir de diligence et sa façon de faire pourra être jugée coercitive. Il faut soigneusement peser les considérations éthiques concurrentes de chaque protocole de recherche.

La Société canadienne des anesthésiologistes croit que le consentement préopératoire à la participation à des recherches cliniques en anesthésie peut être obtenu après l'entrée du patient à l'hôpital, soit la veille ou le jour même de l'intervention chirurgicale, pourvu que:

1. Le patient ne soit pas sous l'influence d'une prémédication.

2. La recherche ne posera pas pour lui un risque sensiblement plus grand que les soins cliniques habituels.

3. Après explication verbale par le chercheur ou un assistant de recherche, on laisse au patient le temps de lire la fiche d'information et de réfléchir aux risques et aux avantages.

4. Le patient doit avoir la possibilité de poser des questions ou d'obtenir des éclaircissements sur quelque point que ce soit concernant la nature de l'étude, les choix, les risques, les avantages, etc.

5. Le patient qui se sentira contraint ou qui estimera avoir besoin de plus de temps pour prendre une décision devrait être exclu de toute participation à l'étude.

6. Les chercheurs documentent au dossier médical la nature du processus d'obtention du consentement des patients qui acceptent de participer à un protocole de recherche.

Personnes approchant les participants pour obtenir le consentement

Dans le cas des protocoles qui exigent de fournir des informations à l'avance aux patients parce que, pour eux, les risques seront plus grands ou l'investissement en temps plus important, ou pour des raisons administratives liées aux protocoles en question, le chercheur principal et le
CÉR s'entendront sur un mécanisme éthique et pratique permettant de le faire. ${ }^{\mathrm{C}}$

Protection des renseignements personnels et confidentialité

La protection des renseignements personnels porte sur le droit d'un participant à une étude de décider dans quelle mesure des renseignements sur sa personne qui ne sont pas déjà du domaine public sont accessibles. La confidentialité concerne la conservation de l'anonymat du sujet lors du traitement des données pendant la recherche et lors de leur utilisation ultérieure dans l'enseignement, les présentations scientifiques et des publications.

Comme pour toute recherche clinique, la protection des renseignements personnels et la confidentialité doivent être respectées en tout temps. Les chercheurs doivent connaître les lois pertinentes restreignant l'utilisation de renseignements personnels sur la santé à des fins de recherche dans leur juridiction respective. À cet égard, la nature et le type de renseignements dont on aura besoin pour l'étude doivent être documentés, et si ces renseignements seront utilisés à d'autres fins, le sujet en sera informé dans le cadre du processus de consentement.

\section{Risques et avantages éventuels}

La nature de nombreux essais cliniques en anesthésie (par ex. la comparaison des caractéristiques de rétablissement et les rapports coûts/avantages de différents types d'anesthésie générale) est telle que le risque principal est lié à l'anesthésique même, et non à la participation au protocole d'étude. En revanche, le recours à des techniques de monitorage effractives pour évaluer les effets cardiovasculaires d'un nouvel anesthésique comporte le risque de complications qui, quoique rares, peuvent être graves. Il incombe toujours au chercheur et au CÉR de s'assurer que les avantages prévus l'emportent sur les risques possibles.

\footnotetext{
$\overline{\mathrm{C}}$ À titre d'exemple, dans certains centres l'infirmière de recherche est considérée comme faisant partie de l'équipe du département et communique avec les patients susceptibles de participer à la recherche pour leur demander s'ils sont intéressés à y participer. Si le patient est intéressé, l'infirmière de recherche explique l'étude et obtient le consentement. Le consentement est alors obtenu par écrit aussitôt que possible. Cette pratique est acceptée par certains comités d'éthique de la recherche. Dans les cas où une telle approche n'est pas acceptable pour le CÉR en charge, et dans le cas d'études entraînant davantage qu'un risque minimal, les patients pourraient être approchés et leur consentement obtenu à la clinique d'évaluation préopératoire. L'anesthésiologiste doit demander si le patient est intéressé ou non à participer à une étude de recherche; si le patient répond par l'affirmative, un membre du personnel de recherche pourra ensuite approcher le patient pour présenter en détail l'étude et demander son consentement éclairé.
} 
Lorsqu'un sujet accepte de participer à une recherche, il en accepte les risques et les avantages. Il faut l'informer de la probabilité des risques et de l'importance et du caractère des inconvénients éventuels. Il faut évaluer la probabilité d'un risque donné, sa durée et sa réversibilité possible. Les chercheurs doivent aussi être prêts à prouver qu'il n'existe aucune autre méthodologie raisonnable qui permettrait d'éviter ou de réduire les risques possibles.

Les avantages éventuels d'une recherche se situent à plusieurs niveaux: le sujet, les futurs patients, de tierces parties, la société ou un segment de la société, et l'accroissement général des connaissances humaines.

\section{Placebos}

L'utilisation de placebos dans un protocole d'étude contrôlée en anesthésie est contraire à l'éthique lorsqu'il existe un traitement efficace établi pour l'état sous étude. ${ }^{\mathrm{D}}$ L'utilisation légitime de placebos se fonde sur le concept de l'équilibre clinique ('clinical equipoise'), qui n'existe que lorsque les experts du milieu médical doutent sincèrement des mérites thérapeutiques relatifs des deux bras d'un essai clinique. On s'attend à ce qu'un essai clinique soit conçu de telle sorte que, s'il est couronné de succès, il procurera des données probantes en faveur de l'un des traitements. ${ }^{\mathrm{E}}$

L'utilisation éthique d'un placebo dans un groupe témoin exige qu'il y ait désaccord entre les spécialistes praticiens quant au traitement préféré. «Un traitement non validé peut être comparé à un placebo dans une étude clinique contrôlée contre placebo dans les cas suivants: (1) il n'existe pas de traitement reconnu, (2) il a été démontré que le traitement reconnu ne valait pas mieux que le placebo, (3) la thérapie reconnue est un placebo, (4) la thérapie reconnue est toxique ou marginalement bénéfique, ou (5) un traitement validé existe mais il n'est pas possible de l'offrir pour des raisons de coût ou d'approvisionnement. Il convient d'administrer un placebo en tant que traitement témoin dans un essai clinique lorsque le nouveau traitement non validé est un ajout à la thérapie conventionnelle (de sorte que la comparaison se fait entre la thérapie reconnue plus le nouveau traitement et la thérapie reconnue et le placebo). ${ }^{\mathrm{F}}$

\footnotetext{
$\bar{D}$ Énoncé de politique des trois conseils, www.pre.ethics.gc.ca.

E Freedman B. Equipoise and the ethics of clinical research. N Engl J Med 1987; 317: 141-5.

F Huston P, Peterson R. Withholding proven treatment in clinical research. N Engl J Med 2001; 345: 912-4.
}

\section{Conflits d'intérêt}

Tous les conflits d'intérêt potentiels doivent être déclarés aux participants d'un essai clinique et mentionnés dans le formulaire de consentement ainsi que dans toute publication subséquente. Les récompenses financières ou matérielles aux chercheurs doivent aussi être déclarées au comité d'éthique de la recherche. Les soins cliniques doivent toujours avoir préséance sur la recherche. Lorsque le même anesthésiologiste conduit des travaux de recherche sur un participant et est aussi celui qui lui fournira des soins d'anesthésie, le protocole de recherche qu'aura approuvé le comité d'éthique de la recherche indiquera clairement à quel moment le protocole de recherche sera abandonné au profit du bien-être ou de la sécurité du patient.

Rémunération des participants à une étude

On ne doit pas inciter les gens à accepter de devenir des sujets d'étude au moyen de promesses de récompense en contrepartie de risques inhérents à l'étude qu'ils ne prendraient pas autrement. De même, on ne doit pas attendre des sujets qu'ils subventionnent la recherche en subissant des pertes monétaires ou de quelque autre nature que ce soit. En gardant ces concepts à l'esprit, la quantité et le type de rémunération doivent être divulgués au comité d'éthique de la recherche.

\section{Populations vulnérables}

Les populations vulnérables comprennent les patients n'ayant pas la capacité de prendre une décision ou dont cette capacité est douteuse et ceux qui ont peut-être cette capacité, mais qui sont vulnérables en raison de la maladie dont ils souffrent, de leur culture ou de leur incapacité à parler une langue. Les patients devant subir une chirurgie pourraient se sentir stressés et sont potentiellement vulnérables à la coercition, particulièrement si le médecin traitant et le médecin chercheur ne sont qu'une seule et même personne. Il est contraire aux règles d'éthique d'exploiter les populations vulnérables et les anesthésiologistes doivent tenir compte de cette contrainte lorsqu'ils recrutent des participants pour un essai clinique. En général, on choisira si possible des gens pleinement aptes plutôt que des gens inaptes ou dont l'aptitude est douteuse.

Études sexospécifiques et pédiatriques

Les protocoles de recherche doivent utiliser des modèles et des populations adaptés, en tenant compte des questions de sexe et d'âge. En particulier, il est important que les recherches en anesthésie se poursuivent chez les femmes capables de procréer et dans la population pédiatrique, 
étant donné qu'il serait contraire à l'éthique de refuser à ces groupes les avantages liés aux progrès réalisés dans la spécialité. Les chercheurs et les comités d'éthique de la recherche ont tout spécialement la tâche de protéger les enfants sujets d'étude et les personnes d'autres populations vulnérables de risques indus d'inconvénients, surtout lorsque le consentement ou la permission est obtenu d'une tierce personne. L'approbation pour participer à la recherche doit être obtenue des enfants d'âge adéquat tel que déterminé de concert avec le comité d'éthique de la recherche.

\section{Aptitude au consentement}

L'aptitude à consentir à participer à une étude ne signifie pas que les patients soient compétents à tous les égards et à toutes les fins. L'aptitude à prendre une décision n'est pas une évaluation globale, mais une évaluation fonctionnelle qui ne porte que sur la prise de décision. Par exemple, un patient inapte à gérer ses finances peut être apte à consentir à participer à une recherche.

Le protocole d'études susceptibles de recruter des personnes aux capacités cognitives amoindries devra comprendre une évaluation de leur aptitude. En outre, une personne inapte ou dont l'aptitude est douteuse ne doit pas être incluse dans une étude qui comporte plus que des risques mineurs et ne lui apporte aucun avantage substantiel potentiel. De plus, un chercheur qui recrute des personnes inaptes pour une étude devra expliquer au CÉR comment l'autorisation d'un tiers sera obtenue, et indiquer que les intérêts de ces sujets seront protégés.

Competing interests None declared.

\section{Appendice: LIGNES DIRECTRICES 2011 POUR LA PRATIQUE DE LA RECHERCHE EN ANESTHÉSIE}

\section{MODÈLE DE FORMULAIRE DE CONSENTEMENT}

Projet de recherche

Investigateurs

Organisme de financement

Ce formulaire de consentement, dont un exemplaire vous a été remis, n'est qu'un élément de la procédure de consentement éclairé. Il doit vous fournir une idée globale de l'objet de la recherche et vous informer sur ce que votre participation impliquera de votre part. Si vous souhaitez davantage de détails sur l'un des points qui y sont mentionnés, ou une information qui n'y figure pas, vous ne devez pas hésiter à poser des questions. Veuillez prendre le temps de lire attentivement ce document et de comprendre toute information qui l'accompagne.

(Les investigateurs doivent fournir les renseignements suivants dans une langue facile à comprendre, en évitant tout jargon professionnel et en donnant une explication des termes essentiels. Ceci est un modèle de formulaire de consentement. Si certains éléments ne sont, de toute évidence, pas pertinents, il n'est pas nécessaire de les inclure. N.B. La majorité des Comités d'éthique de la recherche ont des modèles de formulaire de consentement similaires qui devront être utilisés).

1. Objectif du projet de recherche.

2. Description de tous les produits et procédures expérimentales, y compris l'identification de ceux qui ne feraient pas partie des soins habituels.

3. Explication de certains aspects du plan de recherche, tels que la randomisation et le double insu. Dans le cas du double insu, les détails expliquant quand un code peut être rompu, l'explication et le consentement final après l'explication doivent être inclus.

4. Description de la probabilité de toute gêne et inconvénient associés à la participation et des risques connus ou suspectés à court et à long terme.

5. Des descriptions détaillées de ce que la participation impliquera (procédures de routine, temps à consacrer, natures des tests et procédures, etc.).

6. Probabilité et nature des bénéfices directs et indirects pour les sujets eux-mêmes et pour les autres.

7. Identification des alternatives au recrutement dans la recherche avec discussion des risques, bénéfices, etc. de ces autres options. (Quand il y a lieu, cette information peut être faite oralement ou jointe au formulaire de consentement en faisant référence à ce point-ci).

8. Explication des personnes qui auront accès à l'information collectée et à l'identité du sujet, y compris la façon dont sera assurée la confidentialité des données.

9. Explication sur la façon dont les sujets recevront une information nouvelle ou une mise à jour pendant le déroulement de la recherche.

10. Description de toutes les dépenses auxquelles le sujet pourrait s'exposer comme condition ou du fait de sa participation à la recherche.

Votre signature au bas de ce formulaire indique que vous avez compris, à votre entière satisfaction, l'information concernant votre participation au projet de recherche et que vous acceptez d'y participer comme sujet de recherche. Vous ne renoncez en aucune façon à vos droits légaux et ne dégagez en rien les investigateurs, promoteurs ou établissements concernés par la recherche 
de leurs responsabilités légales et professionnelles. Vous êtes libre de vous retirer de l'étude à tout moment sans aucune conséquence pour vos soins de santé, Votre participation continue doit bénéficier de la même information que votre consentement initial et vous ne devez donc pas hésiter à demander des éclaircissements ou de nouveaux renseignements tout au long de votre participation. Si vous avez d'autres questions, veuillez communiquer avec:

Nom de l'investigateur responsable ou de son représentant qualifié

Adresse et numéro de téléphone pour obtenir de l'information

(Signature du sujet ou de son représentant)

Nom du témoin

Signature du témoin

Date

\section{Autres ressources}

1. World Medical Association. Declaration of Helsinki. Recommendations Guiding Medical Doctors Involving Human Subjects. Available from URL: www.wma.net/en/20activities/ 10ethics/10helsinki/index.html (accessed August 2011).
2. Luce JM, Cook DJ, Tramer TR, et al. The ethical conduct of clinical research involving critically ill patients in the United States and Canada: principles and recommendations. Am J Resp Crit Care Med 2004; 170: 1375-84.

3. Weijer C, Dickens B, Meslin EM. Bioethics for clinicians: 10. Research ethics. CMAJ 1997; 156: 1153-7.

4. ICH. WHO: Guidelines for Good Clinical Practice for Trials on Pharmaceutical Products ICH E6 (R1): Good Clinical Practice: Consolidated Guidance. Available from URL: www.ich.org (accessed August 2011).

5. Guidance for Clinical Investigators, Sponsors, and IRBs Adverse Event Reporting to IRBs - Improving Human Subject Protection U.S. Department of Health and Human Services; Food and Drug Administration; Office of the Commissioner (OC); Center for Drug Evaluation and Research (CDER); Center for Biologics Evaluation and Research (CBER); Center for Devices and Radiological Health (CDRH); Good Clinical Practice Program (GCPP) January 2009. Available from URL: http://www.fda. gov/downloads/RegulatoryInformation/Guidances/ UCM126572.pdf (accessed August 2011).

6. Health Canada. Drugs \& Health Products. Compliance \& Enforcement. Good Clinical Practices. Regulations. Available from URL: www.hc-sc.gc.ca (accessed August 2011).

7. Office of the Privacy Commissioner of Canada. Personal Information Protection and Electronic Documents Act (PIPEDA). Available from URL: www.priv.gc.ca (accessed August 2011). Readers should also consult relevant provincial privacy legislation.

8. Weijer C. The ethical analysis of risk. J Law Med Ethics 2000; 28: 344-61. 